\title{
Contrasting Tsongkhapa and Longchenpa: Buddhist Diversity as a Resource for Comparative Theology
}

\author{
John Makransky, PhD, Boston College, May 2018
}

What often renders interreligious dialogue unproductive is the tendency for dialogue partners to essentialize their traditions, as if each were a uniform entity, e.g. "Buddhism says this; Christianity says that." Dr. Perry Schmidt-Leukel argues that when we investigate the diversity of views in each religion on fundamental theological subjects, we find differences within each religion comparable to the kinds of differences we find between different religions. Schmidt-Leukel's fractal theory of religions thus de-emphasizes uniformity by highlighting the tremendous internal diversity found in each religion. ${ }^{1}$ This means when we notice areas of doctrinal tension in one religion that generate competing intra-religious views of fundamental theological subjects, we may be discovering a resource to inform analogous doctrinal tensions equally fundamental in other religions. Buddhist thinkers have diverse, competing understandings of their doctrines, which can be seen to correspond to analogous doctrinal tensions in other religions.

In this essay, I will discuss contrasting ways of relating human beings to ultimate reality in several areas of Buddhist reflection, focusing on Tibetan Buddhism as example. I will focus on two major figures of fourteenth to fifteenth century Tibet, Tsongkhapa (1357-1419) and Longchen Rabjampa (1308-1364) who share basic doctrinal themes of Buddhism, yet differ considerably in their understanding of those themes. Their views represent poles of tension in Buddhism that frame a spectrum of possible positions on each theological subject. I will summarize the differing positions of these two scholars on the following Buddhist subjects: How ultimate reality (nirvāṇa) is related to the world (samsāra), how ultimate reality is related to persons (theological anthropology), how a Buddhist practitioner accesses ultimate reality to progress on the path of enlightenment (soteriology), and how he or she develops enlightened forms of awareness (gnoseology).

\footnotetext{
${ }^{1}$ Perry Schmidt-Leukel, Religious Pluralism \& Interreligious Theology: The Gifford Lectures (Maryknoll, New York: Orbis Books, 2017, 222-245.
} 
My aim is to invite you, the reader, to explore if you see analogous areas of tension in your own religion in light of Tibetan Buddhism, with regard to theological anthropology, soteriology, gnoseology and other theological topics of reflection. Many theologians who study other religions find, to their surprise, that in some areas of thought they are closer to certain theologians of another religion than they are to many theologians of their own religion. A fractal perspective on religions suggests that this is not an anomaly, but to be expected, since intrareligious reflection often engages the same kinds of theological tensions found in other religions. If you, the reader, see areas of doctrinal tension in your own religious tradition analogous to those described here in Tibet (as I expect you will), perhaps that can shine new light on your own religion.

First, some observations on diverse Buddhist ways of understanding the relation between nirvāṇa and saṃsāra—nirvāṇa as an ultimate, unconditioned reality whose realization brings freedom from inmost causes of suffering, and sampāara as the mundane, conditioned reality of ordinary experience that is laced with causes of suffering.

In the Indian Abhidharma Buddhist systems of Sarvāstivāda and Theravāda, which developed in the centuries after Gautama Buddha, saṃsāra and nirvāṇa are framed as a simple dualism of conditioned and unconditioned realities, respectively. For a person to fully realize the unconditioned, nirvāṇa, is to be liberated from, and ultimately to bring an end to, all conditioned causes and experiences of her suffering and rebirth in samsāara. ${ }^{2}$ Indian Mahāyāna systems that emerged in the early centuries CE re-framed nirvāṇa and saṃsāra as a non-dualism, in which nirvāṇa is understood, in some sense, as fundamentally not separate from saṃsāra. ${ }^{3}$ But there is a diversity of views within different Mahāyāna traditions on how that non-dualism is to be understood and practiced.

Two different ways of interpreting the Mahāyāna non-dualism of nirvāṇa and saṃsāra were taught by two leading figures of Tibetan Buddhism: Tsongkhapa, founder of the Geluk

\footnotetext{
${ }^{2}$ Rupert Gethin, The Foundations of Buddhism (New York: Oxford University Press, 1998), 77; Steven Collins, Nirvana and Other Buddhist Felicities: Utopias of the Pali Imaginaire (Cambridge: Cambridge University Press, 1998), 141, 150, 198-99; John Makransky, Buddhahood Embodied: Sources of Controversy in India and Tibet (Albany: State University of New York Press, 1997), 27-28.

3 Peter Harvey, An Introduction to Buddhism, Second Edition (New York: Cambridge University Press, 2013), 158, 161; Paul Williams, Mahāyāna Buddhism: The Doctrinal Foundations, Second Edition (New York: Routledge, 2009), 60, 185-6; Makransky, Buddhahood Embodied, 85-108.
} 
traditon, and Longchenpa (1308-1363), a leading theorist of the Nyingma, Dzogchen tradition. These pioneering figures, in roughly the same period, wrote treatises on Buddhist thought and practice independently of each other, developing different systematic frameworks of understanding from the concepts and practices of earlier streams of Indo-Tibetan Buddhism.

\section{Theological Anthropology: How Ultimate Reality (Nirvāṇa) Is Related to the Person.}

Tsongkhapa's anthropology is based on Indian Sarvāstivāda Abhidharma ways of systematizing Buddhist philosophy and psychology, informed by the ontology and epistemology of the Madhyamaka school of Indian Mahāyāna Buddhism. For Tsongkhapa, following Abhidharma analysis, persons are composed only of impermanent, conditioned phenomena that are thoroughly tainted by deluded tendencies. These conditioned phenomena are summarized in five categories, the five 'aggregates' (S. skandha, T. phung po), which include all aspects of mental and physical experience: 1) the experience of our physical body and world, 2) sense consciousnesses, 3) perceptions that distinguish and label things, 4) feeling tones associated with all our experiences, and 5) volitional formations, which include chains of thought, intentions, emotions and all other complex mental states. ${ }^{4}$ For Tsongkhapa, following Abhidharma, those five aspects of experience comprise our entire being, and are inseparable from many kinds of suffering because they are the fruition of actions (S. karma, T. las) that are motivated by deluded tendencies of ignorance, attachment and aversion (S. kleśa, T. nyon mongs). The dependent arising of sentient beings, including human beings, follows the twelve-link formula that is explained in Abhidharma traditions: ignorance (S. avidyā), the mind's deluded tendency to reify and identify with its conceptual constructs of self and others, conditions volitional formations in reaction to those constructs (samskāra), which imprint into consciousness (vijñāna) tendencies to construct, reify and react in similar ways. Those karmic tendencies influence one's physical and mental capacities (nāma rūpa) and senses (āyatana), thus effecting one's sense experiences (sparśa) which give rise to pleasant, unpleasant and neutral feeling tones (vedanā). The feeling tones of experiences bring out the mind's karmic tendencies to react with various forms of

\footnotetext{
${ }^{4}$ Transliterations of Sanskrit and Tibetan terms are initially signified by "S." and "T." Where two different terms are given, the first is Sanskrit, the second is Tibetan.
} 
craving (trș̣na), which condition forms of grasping (upādāna), which give rise to self-clinging ways of being (bhava), which condition repeated rebirth (jāti), aging and dying (jarā marana). ${ }^{5}$

For Tsongkhapa then, the very source of our being is ignorance, together with the deluded tendencies it supports (which are various expressions of craving and grasping), and the karmic reactions those tendencies condition, which, together with all other factors of dependent arising, causally generate all experiences of self, others and world as samsāric phenomena of suffering and repeated rebirth. As Tsongkhapa summarizes in his Great Treatise on the Stages of the Path, the origin of samsaara for all beings involves just three fundamental things: how deluded tendencies arise, how they cause beings to accumulate karma, and how karma generates the conditions for their repeated dying and rebirth. ${ }^{6}$

However, from Tsongkhapa's Madhyamaka perspective, the mental and physical aggregates that comprise what we are, and the delusions and karma that generate those aggregates, are all empty of inherent existence, insubstantial and illusory, even though our minds, from the force of conditioning, tend to grasp them all as if they were substantially existent. Because all phenomena appear only through the force of conditions, and are thus empty of any autonomous entity or self-existence, they can be utterly transformed or brought to an end by altering the conditions that produce them. This is done by methodically practicing all the essentials of the Buddha's teaching, which bring an end to the conditioned causes of one's aggregates of mind and body, by gradually empowering the practitioner to realize the unconditioned, empty, and liberating nature of things which is nirvāna.

In Tsongkhapa's understanding, then, in contrast with Longchenpa's explained below, it is not the case that beings are primordially one with the unconditioned nature of nirvāna and have become lost from it by their identification with conditioned phenomena of delusion, karma and aggregates. Rather for Tsongkhapa, beings are ontologically just those conditioned phenomena. Beings are simply the causal continuity of mental and physical phenomena that has taken shape in repeated saṃsāric rebirth by the causal force of delusion and karma.

In Indian Abhidharma traditions and for Tsongkhapa, Buddhist practice ultimately aims to cut the chain of conditioned causes that produce the five aggregates, that is, to bring an end to

\footnotetext{
${ }^{5}$ Gethin, Foundations, 150-1; Tsongkhapa, Byang chub Lam rim chen mo, Volume One. Translated by the Lam rim chen mo Translation Committee as The Great Treatise on the Stages of the Path to Enlightenment (Ithaca, NY: Snow Lion Publications, 2000), 315-319.

${ }^{6}$ Tsongkhapa, Great Treatise, Vol. One, 298-313.
} 
rebirth, an end to our conditioned existence, by realizing nirvāṇa as an unconditioned dimension of reality that transcends all samsāric conditioning. ${ }^{7}$ As a Mahāyāna teacher, Tsongkhapa uses these Abhidharma concepts not only to empower renunciation of samsāra, which is an urge to be freed from the suffering of the samsāric aggregates, but also to generate compassion for all other beings who suffer similarly. Strong compassion for others then becomes the basis to generate bodhicitta, the aspiration to realize nirvāṇa in its fullest form, buddhahood (apratiștitha nirvāṇa), in order to help many others become liberated from the delusive causes of their conditioned aggregates, by helping them realize the empty, unconditioned nature of phenomena which is the realization of nirvāṇa. ${ }^{8}$

From Tsongkhapa's Mahāyāna perspective, to cultivate the wisdom that knows the empty nature of things, and to conjoin that wisdom with a vast cultivation of compassionate attitudes, vows and activities, can empower a fundamental transformation of one's being that generates endless manifestation and liberating activity in the world to help others by means of the bodies of buddhahood. ${ }^{9}$ To realize fullest enlightenment, then, is to bring an end to the impure aggregates of samsāra and to generate in their place a pure, enlightened set of aggregates that are composed of the qualities, wisdoms and activities of a buddha, which endlessly benefit beings who are caught in saṃsāra.

As a Mahāyāna teacher, Tsongkhapa upholds the view that nirvāṇa and saṃsāra are nondual, but not because he understands nirvāṇa as full enlightenment with all of its qualities to be immanent in persons. Rather, in Tsongkhapa's interpretation, nirvāṇa and saṃsāra are non-dual only in the sense that both are empty of substantial existence, an emptiness that provides the

\footnotetext{
${ }^{7}$ Tsongkhapa, Great Treatise, Vol One, 323-324, 335, 339.

8 Tsongkhapa, Great Treatise, Vol. One, 184. Vol. 3, 119-122.

${ }^{9}$ In traditions of Mahāyāna Buddhism, the fullest form of nirvāṇa is that of a buddha. It is called "unrestricted nirvāṇa (S. apratiștitha nirvāna), because a buddha is freed both from bondage to samsāra and from being absorbed into nirvānic peace in a way that would remove him from saṃsāra (from the world). The unrestricted nirvāṇa attained by a buddha, through the force of his wisdom and compassion, manifests endlessly in the world to help other beings become freed from the sufferings of samsāra. This occurs through what are called the three "buddha bodies" (S. buddha-kāyas). A buddha's non-dual awareness of emptiness is his ultimate identity, his dharma body (S. dharma-kāya). From that empty, aware ground of compassion, visionary forms of buddhahood manifest within pure dimensions of reality to transmit the Dharma to communities of advanced bodhisattvas. These visionary forms are called sambhoga-kāya, bodies of communal joy. From the same empty, aware ground of dharmakāya also come a vast variety of ways that qualities of enlightenment are communicated to ordinary persons in the world, through Dharma teachers, sacred art, natural phenomena, etc. This third dimension of buddhahood is called nirmānakāaya, body of diverse manifestation. On this see John Makransky, "Buddhahood and Buddha Bodies," in Encyclopedia of Buddhism, Robert Buswell, ed. (New York: Macmillan Reference, 2004), 76-79; Makransky, Buddhahood Embodied, 85-108, 289-307; Tsongkhapa, Great Treatise, Vol. Two, 86-99;.
} 
essential freedom for persons to be transformed by long practice of the Dharma toward the realization of a buddha's nirvāṇa that is endowed with all the powers of a buddha's enlightenment. For Tsongkhapa, then, although nirvāṇa and saṃsāra are ontologically non-dual in their emptiness, they are experienced existentially as quite distant from each other. This is because buddhahood as fullest realization of nirvāṇa needs to be generated through a vast and methodical accumulation of its own pure causes that replace the impure causes of samsāra.

Longchenpa, like Tsongkhapa, drew on Indian Abhidharma understandings of the five aggregates and their causal process of dependent origination. But whereas Tsongkhapa understood those aggregates to constitute the very being of persons (which is empty of substantial existence), Longchenpa understood the aggregates as obscuring what persons really are, which is pure awareness (S. vidy $\bar{a}$, T. rigpa) primordially undivided from emptiness and endowed with all capacities of enlightenment. The experience of oneself and world as impure aggregates is what happens when one's primordially pure awareness, always undivided from emptiness and enlightened capacities, becomes identified with delusions of ignorance, attachment and aversion that distort those innate capacities by directing their energies into narrow, self-centered patterns of reaction (karma), which give rise to the experiential process of dependent arising, rebirth and re-death described above. Tsongkhapa understood beings as completely comprised by that conditioned samsāric process, which must be brought to an end and replaced by enlightenment and its qualities. In contrast, for Longchenpa, the process of dependent arising doesn't fully comprise what beings are. Rather, it represents a primordial amnesia through which beings have forgotten what they most deeply are. ${ }^{10}$ Longchenpa's anthropology thus relies less exclusively on Abhidharma than Tsongkhapa and more on Indian Vajrayāna teachings that maintain a strong model of innate buddhahood (tathāgatā-garbha), as the underlying identity of beings.

For Longchenpa, unlike Tsongkhapa, the Mahāyāna principle that nirvāṇa and saṃsāra are non-dual means that all qualities and capacities of buddhahood are immanent in all persons. For Longchenpa, the person is, in her deepest identity, not her conditioned mind but the

\footnotetext{
${ }^{10}$ Longchenpa, rDzogs pa chen po Sems nyid ngal gso rtsa wa dang rang 'grel pa shing rta chen po, Volume One. Trans. by Padmakara Translation Group as Finding Rest in the Nature of Mind (Boulder, CO: Shambhala, 2017), 216-18, 237-41. This text includes a translation of the root text of Sems nyid ngal gso and excerpts from its autocommentary.
} 
unconditioned, primordial nature of her mind, which is the ground of enlightenment immanent in her: an innate awareness (rigpa) that is unconditioned in its emptiness, cognizant clarity, and enlightened capacity. The path of enlightenment for Longchenpa then, unlike Tsongkhapa, is not the new creation of a pure enlightened reality that replaces the impure reality of saṃāra. Rather, the path is a process of recalling, and learning fully to embody, what we already are in the depth of our being. He writes: "Whether or not the adventitious defilements [of delusion] have been purified, from the very time of one's existence as an ordinary [unenlightened] being, the essence of one's awareness is emptiness, its nature is clarity, its way of arising is ceaseless, everything [i.e. every virtue of enlightenment] is present and changeless in the nature of awareness. These are the aspects of the ... [buddha] bodies, which are present in us right now, ... without need of seeking for them from any other source."11

Epistemologically, then, the path of enlightenment involves recognizing how the mind's identification with its reductive, reified concepts of ignorance and delusion has hidden and obstructed its true unconditioned nature of emptiness, clarity and enlightened capacity. Existentially, the path is experienced as a return to one's primordial being, like having forgotten, and then remembering, who you really are. For Longchenpa, when the deep, empty nature of the mind is recognized, the delusive tendencies that had hidden it can no longer function, and the primordial essence of enlightenment is freed to take spontaneous expression as powers, bodies and liberating activities of buddhahood. "The only difference between the case [of an ordinary being and that of an enlightened being] lies in the complete manifestation or otherwise of the mind's nature. It is not that the qualities of enlightenment are nonexistent in the condition of ordinary beings and are generated anew later on. For these qualities are [unconditioned,] beyond all movement and change." "In short ... the bodies and wisdoms of buddhahood dwell primordially within all beings, as inalienably as sunlight in the sun itself."13

\section{Soteriology: The Path to Realization of Buddhahood}

\footnotetext{
${ }^{11}$ Longchenpa, rDzogs pa chen po Sem nyid ngal gso'i gnas gsum dge ba sum gyi don khrid Byang chub lam bzang. Translated by Tulku Thondup in Buddha Mind: An Anthology of Longchen Rabjam's Writings on Dzogpa Chenpo (Ithaca, NY: Snow Lion Publications), 314.

12 Longchenpa, Finding Rest in the Nature of Mind, 206.

${ }^{13}$ Longchenpa, Finding Rest in the Nature of Mind, 219.
} 
Within the general Buddhist understanding that is shared by both of these Tibetan figures, mental patterns of ignorance (S. avidyā) make persons and phenomena appear to be self-existent, as if each were an intrinsically single, substantial, and autonomous entity. Our minds construct, reify and fixate on those appearances of self-existence, reacting to them with various forms of attachment or aversion, which bear karmic fruit as diverse forms of suffering.

To counteract those inner causes of suffering, Tsongkhapa argues, we must use precise forms of analysis and investigation (S. vicāra, T. dpyod pa) to deconstruct the false appearance of persons and things, to reveal their emptiness, their lack of self-existence. For Tsongkhapa, again, the person is composed just of sampsāric aggregates of mind and body. But by cultivating the wisdom that realizes the emptiness of all such phenomena, one can begin to be freed from the causal process of ignorance, attachment and karma that maintain those aggregates. Such freedom dawns when the practitioner starts to generate the supramundane, non-dual awareness of emptiness that comprises inmost liberation, nirvāṇa. However, in Tsongkhapa's Mahāyāna soteriology, unlike the normative soteriologies of Abhidharma systems, one does not thereby seek to abandon saṃsāra for a nirvāna that would leave behind all others who suffer in sampsāra. Instead, together with the growing wisdom of emptiness, one cultivates compassion for all beings, and generates bodhicitta, the urge to realize buddhahood, in order to help them all become freed from their inmost causes of suffering. The aim is to attain the fullest form of nirvāṇa, the unrestricted nirvāna of a buddha (apratiștitha nirvāna which is freed not just from personal attachment to the world but also from all inner obstructions that would impede vast enlightened activity for beings in the world. ${ }^{14}$ That is the path of the bodhisattva.

To support that soteriological process, a bodhisattva makes a vow to remain in saṃsāra for the sake of beings, and to generate all the karmic merit and wisdom necessary to realize buddhahood on their behalf, through many inter-related kinds of meditative, ritual, and ethical practice that empower liberating wisdom and compassionate responsiveness (päramitās). ${ }^{15}$ The compassion for beings in samsāa that is embodied in all such practices becomes the 'glue' that keeps the bodhisattva linked to saṃsāra, displacing the 'glue' of samsāric ignorance and attachment, as he or she generates causes of enlightened activity for beings. Tsongkhapa uses agricultural imagery to describe the causal process that leads to enlightenment. Just as a barley

\footnotetext{
14 Tsongkhapa, Great Treatise, Vol. 2, 19-21.

15 Tsongkhapa, Great Treatise, Vol. 2,102-10.
} 
seed is the specific cause of a barley sprout, while the conditions for that seed to sprout are earth and water, so cultivating bodhicitta, the compassionate urge to become fully enlightened for the sake of beings, establishes the causal seed of buddhahood, while cultivating the wisdom of emptiness establishes the condition for that seed to sprout in the attainment of fullest enlightenment. ${ }^{16}$

For Tsongkhapa, freedom from attachment to the self-existent appearances of conditioned things is accomplished by realizing the ultimate, unconditioned nature of all such appearances, which is their emptiness. Yet for him, the awareness that realizes emptiness is also a conditioned phenomenon, like all forms of consciousness. As such, it provides the basis in a buddha's enlightenment for enlightened activity in the conditioned world. ${ }^{17}$ For Tsongkhapa, then, buddhahood's vast powers of knowledge, compassionate responsiveness and liberating activity are all a product of causes, which are generated by the bodhisattva path, and which replace the ignorance, attachment and tainted karma that were the impure causes of one's saṃsāric experience. In sum, for Tsongkhapa, buddhahood has to be causally generated, by extensive, effortful cultivations of wisdom, compassion and ethical activity that gradually undercut and replace the causes of saṃsāra with vast causes of enlightened awareness, manifestation and activity. ${ }^{18}$

For Longchenpa, in contrast with Tsongkhapa, buddhahood is immanent in persons, so the transformation from saṃsāra to nirvāna does not involve an accumulation of causes for newly generating enlightenment. Rather, it involves a deep recognition of immanent buddhahood - the empty, lucid, unconditioned essence of one's awareness, which is already endowed with all capacities of enlightenment. For Longchenpa, the mind's conditioned tendencies of ignorance, attachment and reaction (karma) have obscured that buddha nature, impeding its primordial capacity for unimpeded love, compassion and wisdom. So for him, practices of the bodhisattva path cannot causally create buddhahood; rather, they attune the practitioner to the buddha nature within, making her receptive to its enlightened capacities so they can manifest of themselves.

\footnotetext{
16 Tsongkhapa, Great Treatise, Vol. 2, 18.

17 Makransky, Buddhahood Embodied, 296-7, 304.

18 Tsongkhapa, Great Treatise, Vol. 3, 129; Vol. 2, 97.
} 
Longchenpa argues that we cannot create the infinite reality of buddhahood described in numerous Mahāyāna Buddhist texts--its all-pervasive wisdom, compassion, and liberating activities, by accumulating finite causes and conditions, no matter how extensively. As he writes in his Treasury of Basic Space, "Since pure enlightened awareness and the bodies of buddhahood are primordially established, there is no causal process for generating them by means of adventitious, conditioned phenomena. If enlightened awareness were the product of causes, it would not occur of itself, and would be a conditioned phenomenon that is subject to destruction. But [buddhahood] is described as spontaneously present, unconditioned, [and unending]."19

A buddha's all-pervading powers and activities of love, compassion and wisdom are based not on prior accumulation of conditioned mental states, but on the unconditioned nature of mind in which the infinite capacity of unconditioned love, compassion and wisdom is primordially immanent. As he writes: "The spontaneously present adamantine heart essence is the essence of awareness, which itself is already timelessly present as buddhahood, analogous to the sun that is [always] actually present. Those who follow other approaches hold that buddhahood is accomplished by a process of effort and achievement that involves causes and conditions. This is like holding that the sun, which is always present, shines only due to causes and conditions that dispel clouds and darkness." Thus, he asserts, "These two kinds of approach are as different as heaven and earth." 20

To realize enlightenment, therefore, one must learn to rely not on finite, conditioned, and changable states of mind (T. sems), no matter how virtuous or lofty, but on the infinite, unconditioned, empty and cognizant essence of all such mental states, which is the ultimate nature of mind (T. sems nyid). As Longchenpa declares: "The truth of primordial purity is not found by striving. Buddhahood makes itself evident within the expanse of self-occurring enlightenment. Since buddhahood has already been [timelessly] accomplished, there is no need

\footnotetext{
${ }^{19}$ Longchenpa, Chos dbyings rin po che'i mdzod. Edited and translated by Padma Translation Committee as The Precious Treasury of the Basic Space of Phenomena (Junction City, CA: Padma Publishing, 2001), 42, 44. The quote is my translation from the edited Tibetan text. On this point, see also Longchenpa, Chos dbyings mdzod kyi 'grel ba Lung gi gter mdzod. Translated by Padma Translation Committee as A Treasure Trove of Scriptural Transmission (Junction City, CA: Padma Publishing, 2001), 119. See also Longchenpa, Finding Rest in the Nature of Mind, 247.

${ }^{20}$ Longchenpa, Treasure Trove of Scriptural Transmission, 105.
} 
to achieve it anew. ... This lucid expanse of primordial awareness does not stray at all from its nature, so do not stray from it!",21

Does Longchenpa, then, reject the many meditative, ritual and ethical practices of Buddhist traditions, like those taught by Tsongkhapa? Not at all. He also teaches such practices in great detail. But, he argues, they promote the attainment of enlightenment not because they create enlightenment, but because they purify the mind of all mental tendencies that obscure its primordially enlightened nature, by harmonizing the mind with that nature. The buddha bodies are pre-existent in the experiential ground of beings, Longchenpa writes, "But they have become obscured and invisible by [mental] defilements while one remains as a living being. Thus, the accumulation of merit through development of the enlightened attitude and so forth cleanses the obscurations [that have hidden] the form bodies [rüpakāya] and the accumulation of wisdom through meditation on voidness and so forth cleanses the obscurations [that have hidden] suchness, the essence body (dharmakāya).",2 The so-called "accumulations" of virtue on the path clear away mental obscurations that have hidden pre-existent virtue; they do not create virtue de novo. The increasing power of virtue on the path is like the waxing moon-it appears as if the moon is increasing in size, when actually the shadow that has hidden the already fully formed moon is lessening. ${ }^{23}$

\section{Gnoseology: How to Access Enlightened Forms of Awareness}

Tsongkhapa's methods for realizing enlightened awareness (gnoseology) are also closely connected to his anthropology. He sets forth these methods at length in his Great Treatise. Since for Tsongkhapa, unlike Longchenpa, enlightened awareness is not immanent in persons, any procedures for realizing it cannot draw on it as an innate capacity. Enlightened awareness, at its core, is a non-dual, non-conceptual knowing of the empty, unconditioned nature of things. To realize the emptiness of things in that non-conceptual way is to be freed from the ignorant habit of misconceiving and reifying things as self-existent, i.e. to be freed from the epistemological basis of attachment, karmic reaction and consequent suffering. But in Tsongkhapa's

\footnotetext{
${ }^{21}$ Longchenpa, Precious Treasury of Basic Space, 54. This quote is my translation from the edited Tibetan text.

${ }^{22}$ Longchenpa, rDzogs pa chen po Sem nyid ngal gso' $i$ 'grel ba shing rta chen po. Translated by Tulku Thondup in Buddha Mind, 240.

${ }^{23}$ Longchenpa, rDzogs pa chen po Sem nyid rang grol. Translated by Tulku Thondup in Buddha Mind, 333-34.
} 
anthropology, human beings are constituted only by psycho-physical aggregates whose mental states are conceptually conditioned to function dualistically. So conceptual states of mind are the only possible starting point for learning to generate a non-conceptual awareness of emptiness. Tsongkhapa therefore articulates ways to employ conceptual, conditioned states of mind as the basis (and only basis) for initially accessing the ultimate truth of emptiness. When through repeated analysis and diverse forms of reasoning, one's conceptual ascertainment that everything is empty of self-existence becomes sufficiently strong, steady and clear, it can gradually deepen into a non-conceptual, non-dual awareness of emptiness that actually liberates the practitioner from the conceptual fixations of ignorance and attachment that bind her to samsāara. ${ }^{24}$

Based on the gnoseological explanations of several late Indian Madhyamaka scholars (prominently the eighth century Indian teacher Kamalaśīla), Tsongkhapa explains that two kinds of conditioned cultivation of mind are needed to realize such enlightened awareness: calm abiding (śamatha) and conceptual investigation into emptiness that can lead to liberating insight (vipaśyanā). Without the alternation of effortful, conditioned mental states of calm abiding and insight and their eventual unification, he argues, the mind's tendency to identify with reified constructs of ignorance and attachment cannot be cut. ${ }^{25}$

Tsongkhapa is aware of other contemplative traditions in India, China and Tibet that focused more exclusively on the practice of calm abiding (śamatha), purportedly to calm the mind so fully that it would stop engaging in activities of conceptual construction and reification that generate the appearance and attachment to self-existence that bind persons to samsāra. But Tsongkhapa severely criticizes that approach, emphasizing the need to balance calm abiding with precisely targeted forms of conceptual analysis into emptiness (vipaśyanā), in order to generate a conceptual understanding of emptiness that, with increasing stability, would become a nonconceptual, liberating insight. ${ }^{26}$ Since in Tsongkhapa's anthropology, no innate, non-conceptual enlightened awareness is available in persons to draw upon, the only way to get to such a non-

\footnotetext{
${ }^{24}$ Tsongkhapa, Great Treatise Vol. 3, 341-342. Tsongkhapa asserts that all key points of the path in their entirety (including emptiness) are within the purview of the conceptual mind that engages scripture and reasoning, and can be accessed only by means of that. Vol. 2, 88, 96.

25 Tsongkhapa, Great Treatise Vol. 3, 342-344.

26 David Seyfort Ruegg, Buddha Nature, Mind and the Problem of Gradualism (London: School of Oriental and African Studies, 1989), 111-115.
} 
conceptual awareness in his understanding is through the conceptually conditioned procedures that he outlines.

Longchenpas' gnoseology is also closely related to his anthropology. And since for Longchenpa enlightened awareness is immanent in persons, the path to enlightenment must ultimately draw on that awareness itself as the primary means for awakening. Recall that in Longchenpa's anthropology (unlike Tsongkhapa's) persons are not comprised only of conditioned aggregates of mind and body. Rather, the conditioned aggregates tainted by ignorance and attachment are just distorted expressions of the unconditioned, untainted primordial unity of emptiness and cognizance that is the insubstantial, immanent ground of all experience. When a person's primordial awareness (T. rigpa) becomes freed from the ignorance and attachment that had obscured it, that awareness can now recognize the aggregates of mind and body as undivided from its own emptiness and cognizance, which is endowed with all powers of enlightenment, thereby permitting the innate wisdoms (T. ye shes), embodiments (T. $s k u$ ) and activities (T. phrin las) of buddhahood that had been hidden in the aggregates to manifest of themselves. ${ }^{27}$

In Longchenpa's view, then, methods for realizing enlightened awareness that draw, as Tsongkhapa does, just on conditioned, conceptual, and dualistic states of mind cannot possibly access the unconditioned, pre-conceptual, and non-dual ground of enlightened mind. As Longchenpa states: "Primordial awareness transcends the reference points of conceptual mind, so do not make mental efforts to apprehend it. The deep nature of mind is effortless and spontaneously perfected, so do not adulterate it with antidotes of modification and transformation: let it go, of itself, in natural ease." 28

For Longchenpa, causal methods to generate enlightened awareness, like those Tsongkhapa taught, cannot attain the state of enlightenment that is unconditioned, since enlightened awareness is not a causal creation. It is beyond the ability of conditioned mental

\footnotetext{
${ }^{27}$ Longchenpa Tshig don mdzod, translated by Sam van Schaik in Approaching the Great Perfection (Somerville, MA: Wisdom Publications, 2004), 68. See also Longchenpa, rDzogs pa chen po Sems nyid rang grol (Gangtok, Sikkim: Pema Thinley, 1999), folios 263-64; translated by Tulku Thondup in Buddha Mind, 327.

${ }^{28}$ Longchenpa, Sems nyid rang grol, folio 258; my translation. Also translated by Thondup, Buddha Mind, 321.
} 
states to generate. ${ }^{29}$ The various kinds of mental cultivation that Tibetan Buddhism inherited from India are incorporated into Longchenpa's path system not as means to causally generate enlightenment but to make practitioners increasingly receptive to the enlightened capacities that are already immanent in the ground of their experience: "Although the sun and moon are radiantly luminous in the midst of the sky, they can be completely hidden by clouds that prevent them from being known. So, enlightenment, though present within you, is not apparent. Thick clouds vanish naturally when left alone. Similarly, the clouds of karmic causality vanish naturally without effort or striving, as the essence of enlightenment shines of itself in the sky-like expanse. But because of varying levels of readiness among practitioners, different systems of practice are provided." ${ }^{30}$

In Longchenpa's view, even a tremendously vast accumulation of finite causes cannot possibly give rise to the infinite expanse of non-dual awareness that is buddhahood. It is the unconditioned, infinite nature of one's mind itself that realizes the infinite expanse of enlightenment as its own primordial way of being (T. gnas lugs). He writes, "The supreme way involves no effort of taking up or rejecting [various states of mind]. Rather, naturally occurring primordial awareness, the essence of enlightened mind, becomes evident by not wavering from its direct experience. So there is no need to strive for [enlightenment] elsewhere." 31

Therefore, in Longchenpa's view, rather than using conceptual analysis as the primary means to undercut the reifying tendencies that bind one's mind to suffering, one must learn to rely on the unity of cognizance and emptiness that is the pre-conceptual ground of all experience, which is prior to all reifying and reactive tendencies and also the very essence of them, in order to heal and ultimately liberate all such tendencies: "All desired, undesired and neutral states of mind ... arise as a display of primordial awareness within its basic space [of emptiness]. All such mental states occur only within that basic space, not wavering from it at all. So, without attempting to change or manipulate them ... just recognize the basic space in which they occur,

\footnotetext{
${ }^{29}$ Longchenpa, Treasure Trove of Scriptural Transmission, 43, 55; Longchenpa, Sems nyid rang grol in Thondup, Buddha Mind, 324.

${ }^{30}$ Longchenpa, Precious Treasury of Basic Space, 130; my translation from the Tibetan text.

${ }^{31}$ Longchenpa, Precious Treasury of Basic Space, 38, my translation. Cf. Longchenpa, Sems nyid Rang grol in Thondup, Buddha Mind, 334.
} 
and rest there. As soon as you do, those mental states subside by themselves, vanish by themselves, are liberated by themselves.",32

For Tsongkhapa, to rest in this way would connote the mere practice of śamatha, calm

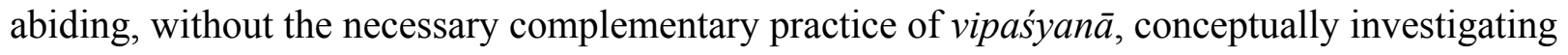
the emptiness of things. Since for Tsongkhapa, all human awareness is ineluctably caught up in forms of fixation whether gross or subtle, even deep states of śamatha, "resting," would not be enough to access the liberating wisdom of emptiness. Analysis that conceptually ascertains emptiness is also essential. For Longchenpa in contrast, primordial awareness beyond all conceptual frames of reference is the very power for awakening to enlightenment. If one does not learn how to let it come to self-recognition, and rest in its capacity to liberate all conceptual fixations as empty appearances, one's application of conceptual analysis will just further impede the self-liberating power of innate enlightened awareness. Although conceptual analysis is a helpful supportive practice, it could never be the main practice for realizing enlightenment.

\section{Implications for Comparative Theology}

I have summarized a few basic tensions in Tibetan Buddhism concerning how ultimate reality is related to human beings in their basic nature, in their capacity to become aware of that reality, and in their capacity to be transformed by it. The worldviews and doctrinal frameworks of Tibetan Buddhist traditions and cultures, of course, differ from those of other religious cultures. But the Tibetan tensions noted here, between transcendent and immanent aspects of anthropology, soteriology, and gnoseology, are paralleled in other religious cultures and traditions.

Did the areas of Tibetan doctrinal tension described above point you, the reader, to analogous areas of tension in your own religious tradition? If so, this becomes a basis for comparative investigation. In what different ways does your tradition attempt to relate an unconditioned, infinite, atemporal ultimate reality (or nature of reality) to the conditioned, finite, temporal world of human beings (theological anthropology)? In light of that, what differing viewpoints emerge on how much, and in what ways, human effort is required to align, or realign, us with that ultimate reality? Or to what extent are human beings dependent on ultimate

\footnotetext{
32 Longchenpa, Precious Treasury of Basic Space, 108; my translation.
} 
reality itself to align us with itself, or to draw us to itself (soteriology)? What perspectives arise regarding how, and to what extent, a human being with finite, conditioned forms of knowing can become aware of an infinite, unconditioned dimension of reality (gnoseology)? Finally, as in Tibetan Buddhism, how are diverse practices of your religion understood to inform and empower all such theological understandings and possibilities, e.g. practices of liturgy, prayer, contemplation, investigation, deepening faith, love, compassion, wisdom, ritual reverence, offering, repentance, ethical practices, and forms of communal life?

If we take Christianity as an example: to what extent is the image of God in the human damaged or intact (theological anthropology)? To what extent are persons saved by grace through faith, or by human disciplines and works (soteriology)? What is the beatific vision? Does it involve seeing God "face to face," or does it involve beginning to see beings and things as God sees them (gnoseology)? Similar questions may occur to theologically trained persons of any religion, after being exposed to analogous tensions in any other religion, like the exposure to Tibetan Buddhist tensions that we engaged in this essay. 